\title{
Pengembangan Modul Pelatihan Pembuatan Gerabah Di Desa Masbagik Timur
}

\author{
${ }^{1}$ Muhamad Ali, ${ }^{2}$ Ana Aprilianti \\ 1,2, Prodi Pendidikan ekonomi, FISE Universitas Hamzanwadi \\ Email: 1,2, aliejoangs@gmail.com, ana.aprilianti@yahoo.co.id
}

Received: 15 Februari, 2019; Accepted: 27 Maret, 2019; Published: 30 Juni, 2019

\begin{abstract}
Abstrak
Tujuan penelitian ini adalah : (a) untuk menghasilkan modul pelatihan pembuatan gerabah di desa masbagik timur, (b) untuk menjelaskan keefektifan modul pelatihan pembuatan gerabah, panduan pelatihan di desa masbagik timur. Metode penelitian Research and Development (R\&D). tahapan pengembangan produk, (a) penyusunan modul pelatihan, (b) panduan pembuatan gerabah, dan (c) penilaian. Teknik pengumpulan data menggunakan observasi, wawancara dan angket. Teknis analisis data, (a) kevalidan, (b) keterbacaan, dan (c) keefektifan. Validasi modul dilakukan oleh pakar dan praktisi. Uji coba modul meliputi uji coba terbatas terhadap 6 orang masyarakat dan uji coba di perluas terhadap 10 orang masyarakat Desa Masbagik Timur. Hasil penelitian menunjukkan; (1) produk yang di validasi pakar dan praktisi memperoleh rerata skor 2,0\% (kualifikasi baik), (2) modul final pelatihan hasil pengembangan layak digunakan. Keterbacaan rerata 3,7 $\%$ (kualifikasi baik), terdapat kepraktisan dalam menggunakan modul pelatihan ini dengan rerata 3,,6 \% (kualifikasi baik), modul efektif untuk digunakan. Simpulan penelitian bahwa modul pelatihan pembuatan gerabah dan panduan peatihannya layak digunakan oleh masyarakat di Desa Masbagik Timur Kecamatan Masbagik.

Kata Kunci : Pengembangan Modul Pelatihan, Panduan Pelatihan
\end{abstract}

\begin{abstract}
Research on development of training module of making pottery is very important to build new entrepreneur in increasing economic activity of society. This research and development aims to produce vessel training modules, training manuals and to explain the effectiveness of pottery-making training modules, training manuals to improve economic activities of communities in Masbagik Timur Village. Research and Development (R \& D) research methods. Stages of product development, (a) preparation of training modules, (b) guide on making pottery, and (c) assessment. Data collection techniques used observation, interviews and questionnaires. Data analysis techniques, (a) validity, (b) readability, and (c) effectiveness. Module validation is done by experts and practitioners. The module trials include a limited trial of 6 communities and an expanded trial of 10 Masbagik Timur Village communities. The results showed; (1) validated products of experts and practitioners get a mean score of $2.0 \%$ (good qualification), (2) final module development training worthy of use. Average readability 3.7 (good qualification), there is practicality in using this training module with a mean of 3.6 (good qualification), effective module to use. The conclusion of the research is that the training module of pottery making and its training manual is feasible to be used to improve the economic activity of Masbagik Timur Masbagik Village community.

Kata Kunci : Development of Training Module, Training Guide
\end{abstract}




\section{PENDAHULUAN}

Melakoni usaha kerajinan gerabah di tengah lesunya pasar dan semakin besarnya tekanan barang-barang perabotan berbasis produksi pabrik, menjamurnya gerabah impor serta berbagai kendala lainnya, merupakan sebuah upaya luar biasa untuk dapat mempertahankan eksistensi produksi kerajinan gerabah di daerah ini.

Tradisi pembuatan gerabah tradisional yang diturunkan secara turun temurun dari nenek moyang kita sekarang ini sudah mulai punah, karena banyaknya faktor produksi yang lebih modern. Kebanyakkan masyarakat terutama pengrajin gerabah yang lebih memilih profesi lain sebagai usahanya karena di nilai jauh lebih menguntungkan. Kondisi inilah yang membuat peneliti ingin membuat sebuah buku panduan/modul yang berisi tentang pembuatan gerabah yang nantinya akan di pakai untuk mengajarkan tradisi pembuatan gerabah kepada generasi muda khususnya, agar tradisi pembuatan gerabah ini akan tetap ada meski maraknya usaha-usaha modern lainnya.

\section{METODE PENELITIAN}

Penelitian ini menggunakan metode Research and Development $(R \& D)$, prosedur penelitian yang digunakan mengadopsi dari Borg and Gall (2006:169170) yang terdiri dari sepuluh langkah. Kemudian oleh peneliti disederhanakan menjadi lima langkah, yakni : (1) Pendahuluan, (2) Pengembangan Produk Awal, (3) Uji Produk Awal, (4) Uji Produk Akhir, dan (5) Produk Akhir.

Instrumen pengumpulan data menggunakan (1) lembar observasi, (2) wawancara, dan (3) angket. Teknik analisis data menggunakan teknik analisis deskriptif kualitatif yang digunakan untuk mengolah data-data kualitatif berupa deskripsi/paparan hasil observasi, wawancara, angket kebutuhan, dan kondisi modul pelatihan pembuatan gerabah. Teknik analisis data terdiri dari kevalidan, keterbacaan, dan keefektifan. Untuk kepentingan pengembangan modul pelatihan dilakukan uji coba terbatas dan uji coba diperluas. Uji coba terbatas dilaksanakan oleh 6 orang masyarakat dan pada uji coba diperluas dilaksanakan oleh 10 orang 
masyarakat. Kegiatan uji coba disamping menguji keterlaksanaan modul pelatihan juga untuk mengetahui kelayakan modul pelatihan yang digunakan, sehingga menghasilkan produk yang diharapkan.

\section{HASIL DAN PEMBAHASAN}

Berdasarkan penelitian pendahuluan terhadap penyelenggaraan pelatihan pembuatan gerabah selama ini diperoleh gambaran bahwa secara umum penyelenggaraan pelatihan pembuatan gerabah selama ini dipersepsi responden kurang baik. Hal ini didasarkan pada jawaban responden dari wawancara yang diberikan. Analisis kebutuhan merupakan upaya untuk mengetahui hal apa saja sebenarnya yang dibutuhkan oleh peserta dalam pelatihan. Penilaian hasil pelatihan dengan kriteria yang telah ditentukan. Kriteria hasil pelatihan yang dimaksud dalam penelitian ini disajikan dalam Tabel 4.7.

\section{Tabel 1}

$\underline{\text { Persentase dan Tingkat Keterampilan Proses Belajar Masyarakat }}$ No. $\quad$ Persentase (\%) Tingkat Keterampilan Proses Belajar

\begin{tabular}{lcc}
\hline $\mathbf{1}$ & $6-10$ & Sangat Efektif \\
\hline $\mathbf{2}$ & $1-5$ & Efektif \\
\hline $\mathbf{3}$ & $(-4)-0$ & Kurang Efektif \\
\hline $\mathbf{4}$ & $(-10)-(-5)$ & Tidak Efektif \\
\hline \multicolumn{2}{c}{ Diadaptasi dari Akbar $(2013: 41)$}
\end{tabular}

Adapun perolehan nilai rata-rata hasil pelatihan masyarakat dapat disajikan dalam Tabel 4.8 berikut ini.

Tabel 2

Perolehan Hasil Belajar Masyarakat

\begin{tabular}{ccc}
\hline No. & Nama & Nilai \\
\hline $\mathbf{1}$ & Marianah & 3,9 \\
\hline $\mathbf{2}$ & Isma & 2.8 \\
\hline $\mathbf{3}$ & Nur & 3,8 \\
\hline $\mathbf{4}$ & Suratni & 3,8 \\
\hline $\mathbf{5}$ & Haeruni & 3,6 \\
\hline $\mathbf{6}$ & Suri & 3,9 \\
\hline $\mathbf{7}$ & Nuraeni & 3,7 \\
\hline $\mathbf{8}$ & Muliadi & 3,6 \\
\hline $\mathbf{9}$ & Nurdin & 3,8 \\
\hline $\mathbf{1 0}$ & Haeril & 3,6 \\
\hline & Rata-rata & $\mathbf{3 , 6}$
\end{tabular}

Sumber: Akbar (2013:41) 
Adapun tabel distribusi frekuensi hasil pelatihan masyarakat dapat dilihat pada tabel 4.9 berikut :

Tabel 3

Distribusi Frekuensi Variabel Hasil Belajar Masyarakat

\begin{tabular}{cccc}
\hline No. & $\begin{array}{c}\text { Interval } \\
\text { kelas }\end{array}$ & Frekuensi & $\begin{array}{c}\text { Frekuensi } \\
\text { Relatif } \\
(\boldsymbol{\%})\end{array}$ \\
\hline $\mathbf{1}$ & $0-2$ & 1 & 2,00 \\
\hline $\mathbf{2}$ & $3-5$ & 9 & 8,00 \\
\hline $\mathbf{3}$ & $6-8$ & 0 & 0 \\
\hline $\mathbf{4}$ & $9-10$ & 0 & 0 \\
\hline & Jumlah & 10 & 10.00 \\
\hline
\end{tabular}

(Sumber: Data primer yang diolah: 2017)

Berdasarkan tabel 4.11 di atas, frekuensi variable hasil belajar masyarakat pada interval $0-2$ sebanyak 1 orang $(2,00 \%)$, interval $3-5$ sebanyak 9 orang $(8,00 \%)$.

Berdasarkan distribusi frekuensi variabel hasil belajar di atas dapat digambarkan diagram batang sebagai berikut :

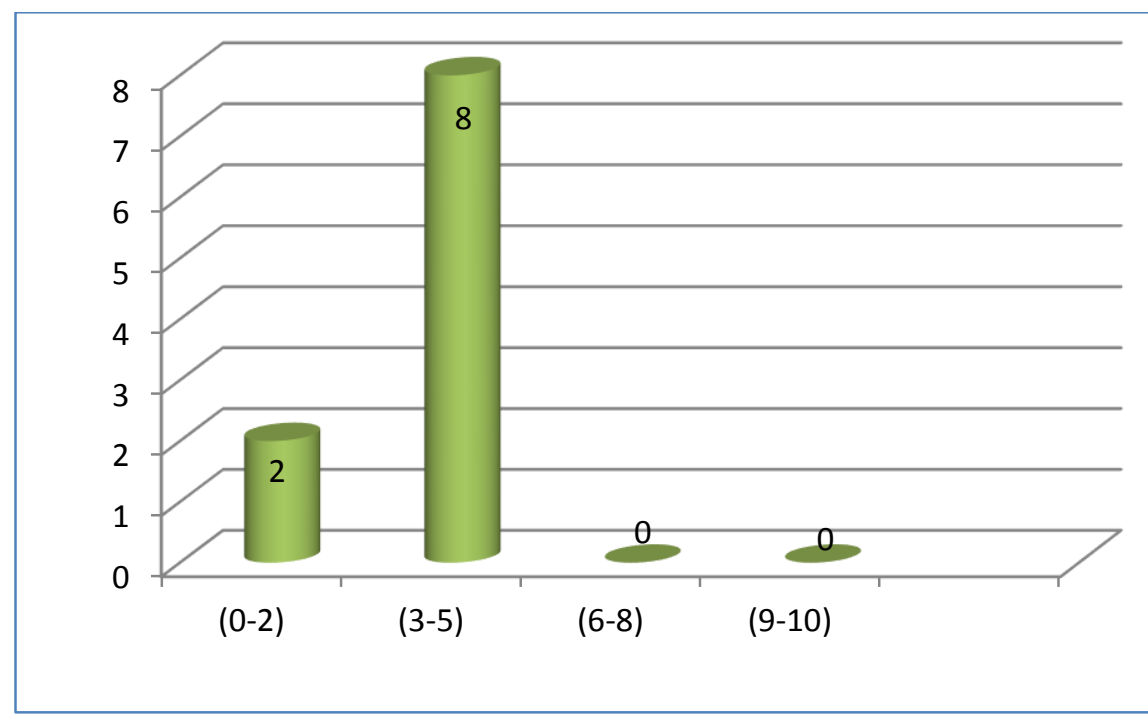

(sumber : Data Primer yang diolah : 2017)

Gambar 4.2 Diagram Batang Distribusi Frekuensi Hasil Belajar

Hasil belajar masyarakat dinilai dengan tes praktik. Pelaksanaan tersebut dilakukan pada saat pelatihan di Desa Masbagik Timur selama 90 menit (2 jam pelajaran). Modul pelatihan pembuatan gerabah yang dihasilkan mulai dari desain modul di validasi pakar/ahli, praktisi dan uji kelayakan melalui pengembangan 
hingga menjadi modul hipotetik, selanjutnya di uji cobakan secara terbatas dan diperluas.

\section{Pembahasan}

Pembahasan hanya mencakup mengenai proses pembuatan modul pelatihan pembuatan gerabah dan keefektifan dalam penyusunan modul pelatihan pembuatan gerabah.

1. Data Uji Coba

Uji coba lapangan merupakan uji coba untuk mengukur layak atau tidaknya buku modul yang dikembangkan. Uji coba kelayakan buku modul yang dihasilkan dilaksanakan di Desa Masbagik Timur pada tanggal 28 oktober 2017. Produk yang diuji cobakan pada masyarakat adalah produk yang telah direvisi berdasarkan masukan-masukan yang didapat dari ahli materi, ahli bahasa dan ahli desain. Pengisian lembar penelitian dilakukan oleh 6 masyarakat Desa Masbagik Timur.

Tabulasi dan data hasil uji coba kelayakan buku modul pada masyarakat dapat dilihat dilampiran. Hasil penilaian uji kelayakan buku modul dapat dilihat pada Tabel 4.13 berikut.

\section{Table 4}

Penilain Aspek Keterlaksanaan Oleh Masyarakat

\begin{tabular}{clc}
\hline No. & \multicolumn{1}{c}{ Aspek yang dinilai } & Skor \\
\hline $\mathbf{1}$ & Materi dalam buku modul lengkap dan mudah dipahami & 3,8 \\
\hline $\mathbf{2}$ & Materi sudah mencakup potensi lokal yang ada & 4 \\
\hline $\mathbf{3}$ & $\begin{array}{l}\text { Kalimat-kalimat yang digunakan dalam buku modul jelas dan } \\
\text { mudah dipahami }\end{array}$ & 3,8 \\
\hline $\mathbf{4}$ & Pentunjuk penggunaan modul sudah jelas dan mudah dimengerti & 3,8 \\
\hline $\mathbf{5}$ & Kemenarikan tampilan fisik buku modul & 3,1 \\
\hline $\mathbf{6}$ & Sampul modul menarik dan mencerminkan isi modul & 4 \\
\hline $\mathbf{7}$ & $\begin{array}{l}\text { Contoh-contoh jelas membantu pemahaman masyarakat dalam } \\
\text { belajar }\end{array}$ & 3,6 \\
\hline $\mathbf{8}$ & $\begin{array}{l}\text { Modul ini dapat memotivasi masyarakat untuk membuat rencana } \\
\text { usaha }\end{array}$ & 4 \\
\hline $\mathbf{9}$ & $\begin{array}{l}\text { Isi dan urutan sesi dalam modul mudah dipelajari tanpa harus } \\
\text { didampingi guru }\end{array}$ & 4 \\
\hline $\mathbf{1 0}$ & Modul ini telah menyertakan sekitar sebagai sumber belajar & 4 \\
\hline $\mathbf{1 1}$ & Soal-soal sesuai dengan modul & $\mathbf{4 1 , 4} \%$ \\
\hline
\end{tabular}

(sumber : Data primer yang diolah : 2017) 
2. Analisis Data

Analisis data adalah data hasil penelitian dan pengembangan yang akan dianalisis adalah data terkait validitas dan keefektivitasan buku modul.

a. Validitas Modul

Data validitas buku modul didapatkan dari penilaian 2 dosen dan 1 guru, yakni ahli materi dan ahli desain yang dilakukan oleh dosen dan ahli bahasa yang dilakukan oleh guru. Hasil validasi tersebut menunjukkan tingkat kevalidan atau kesahihan buku modul dari aspek isi/materi, desain dan bahasa dalam buku modul.

Berikut adalah kriteria validitas yang dimaksud dalam penelitian ini disajikan dalam Tabel 4.14.

Tabel 5

Kriteria dan Tingkat Validitas Modul

\begin{tabular}{ccl}
\hline No. & Kriteria Validitas (\%) & \multicolumn{1}{c}{ Tingkat Validitas } \\
\hline $\mathbf{1}$ & $6-10$ & $\begin{array}{l}\text { Sangat valid, atau dapat digunakan } \\
\text { tanpa revisi }\end{array}$ \\
\hline $\mathbf{2}$ & $1-5$ & $\begin{array}{l}\text { Cukup valid, atau dapat digunakan } \\
\text { namun perlu adanya revisi }\end{array}$ \\
\hline $\mathbf{3}$ & $(-4)-0$ & $\begin{array}{l}\text { Kurang valid, disarankan tidak } \\
\text { dipergunakan karena perlu revisi } \\
\text { besar }\end{array}$ \\
\hline $\mathbf{4}$ & $(-10)-(-5)$ & $\begin{array}{l}\text { Tidak valid, atau tidak boleh } \\
\text { digunakan }\end{array}$ \\
\hline
\end{tabular}

Sumber: Akbar (2013:41)

Berikut adalah rekapitulasi hasil validasi yang diperoleh dari ahli isi/materi, ahli bahasa dan ahli desain disajikan dalam tabel 4.15.

Tabel 6

Rekapitulasi Hasil Validasi Ahli

\begin{tabular}{cccc}
\hline No. & Ahli isi/materi & Ahli bahasa & Ahli desain \\
\hline & $3,6 \%$ & $3,1 \%$ & $1,1 \%$ \\
\hline Rata-rata & & $2,6 \%$ & \\
\hline Sumber: Akbar (2013:41) & &
\end{tabular}

Berdasarkan data pada Tabel 4.15 diketahui bahwa persentase yang diperoleh dari validator untuk tiap-tiap aspek adalah 3,6\% untuk isi/materi buku modul, 3,1 \% untuk bahasa buku modul, dan 1,1\% untuk desain buku modul. Adapun perolehan rata-rata dari ketiga aspek tersebut adalah $2,6 \%$. Setelah skor rata-rata tersebut dimasukkan dalam tabel konversi, 
buku modul pelatihan pembuatan gerabah yang dikembangkan dikategorikan cukup valid.

b. Keterbacaan Buku Modul

Data mengenai tingkat keterbacaan buku modul diperoleh dengan melakukan uji coba kelompok kecil. Peneliti memberikan buku modul yang telah valid berdasarkan hasil validasi ahli kepada enam orang masyarakat Desa Masbagik Timur. Enam masyarakat ini dipilih karena uji keterbacaan harus dilakukan oleh subjek yang telah mendapatkan materi pelatihan pada buku modul pelatihan pembuatan gerabah tersebut sebelum diujicobakan pada subjek uji coba terbatas. Berikut adalah rekapitulasi hasil uji coba keterbacaan tersebut pada tabel 4.16 berikut:

Tabel 7

Rekapitulasi Hasil Uji Keterbacaan

\begin{tabular}{lcc}
\hline \multicolumn{1}{c}{ Nama Masyarakat } & Skor Total & Persentase \% \\
\hline Suri & 43 & $3,9 \%$ \\
\hline Nur & 42 & $3,8 \%$ \\
\hline Nuraeni & 41 & $3,7 \%$ \\
\hline Muliadi & 40 & $3,6 \%$ \\
\hline Suratni & 42 & $3,8 \%$ \\
\hline Haeruni & 40 & $3,6 \%$ \\
\hline Rata-rata & $\mathbf{4 1}$ & $\mathbf{3 , 7} \%$ \\
\hline (Sumber : Data primer yang diolah : 2017)
\end{tabular}

Berdasarkan Tabel 4.16 diketahui bahwa persentase keterbacaan buku modul sebesar 3,7 \%. Skor tersebut kemudian dikoversikan sesuai dengan tebel kriteria keterbacaan buku modul. Adapun kategori keterbacaan yang diperoleh adalah cukup baik. Dengan demikian buku modul tersebut dapat digunakan oleh masyarakat Desa Masbagik Timur.

c. Keefektifan Buku Modul

Data mengenai keefektifan buku modul diperoleh dari hasil analisis terhadap angket yang diberikan kepada masyarakat Desa Masbagik Timur setelah membaca buku modul yang telah divalidasi ahli.

Berikut adalah Kriteria persentase dan tingkat keterampilan proses belajar masyarakat yang dimaksud dalam penelitian ini disajikan dalam tabel 4.17. 
Tabel 8

Persentase dan Tingkat Keterampilan Proses Belajar Masyarakat No. $\quad$ Persentase (\%) $\quad$ Tingkat Keterampilan Proses Belajar

\begin{tabular}{ccc}
\hline $\mathbf{1}$ & $6-10$ & Sangat Efektif \\
\hline $\mathbf{2}$ & $1-5$ & Efektif \\
\hline $\mathbf{3}$ & $(-4)-0$ & Kurang Efektif \\
\hline $\mathbf{4}$ & $(-10)-(-5)$ & Tidak Efektif \\
\hline Diadaptasi dari Akbar $(2013: 41)$ &
\end{tabular}

Berdasarkan uji coba kelas terbatas melalui belajar di saat pelatihan didapatkan skor hasil belajar dan keterampilan proses masyarakat sebagai berikut :

Tabel 9

Rekapitulasi Hasil Belajar Masyarakat

\begin{tabular}{lcl}
\hline No. & Nama & Nilai \\
\hline $\mathbf{1}$ & Marianah & 3,9 \\
\hline $\mathbf{2}$ & Isma & 2.8 \\
\hline $\mathbf{3}$ & Nur & 3,8 \\
\hline $\mathbf{4}$ & Suratni & 3,8 \\
\hline $\mathbf{5}$ & Haeruni & 3,6 \\
\hline $\mathbf{6}$ & Suri & 3,9 \\
\hline $\mathbf{7}$ & Nuraeni & 3,7 \\
\hline $\mathbf{8}$ & Muliadi & 3,6 \\
\hline $\mathbf{9}$ & Nurdin & 3,8 \\
\hline $\mathbf{1 0}$ & Haeril & 3,6 \\
\hline & Rata-rata & $\mathbf{3 , 6}$ \\
\hline
\end{tabular}

Sumber: Akbar (2013:41)

Berdasarkan data pada Tabel 4.20 diketahui bahwa perolehan nilai rata-rata hasil belajar masyarakat sebesar 3,6. Sesuai dengan kriteria yang telah ditentukan, buku modul pelatihan pembuatan gerabah dapat dikategorikan Efektif karena perolehan rata-rata hasil belajar masyarakat lebih dari 3. Dengan telah terpenuhinya kriteria ketercapaian hasil belajar dan keterampilan proses belajar yang telah ditentukan, maka dapat dikatakan bahwa buku modul pelatihan pembuatan gerabah Efektif di gunakan oleh masyarakat di Desa Masbagik Timur.

3. Produk Akhir

Buku modul pelatihan pembuatan gerabah, baik untuk masyarakat maupun pegangan untuk pemilik usahanya sendiri yang dikembangkan 
sebagai buku modul cetak. Buku modul cetak dipilih karena memiliki beberapa kelebihan di antaranya praktis, relatif ringan, mudah dibawa dan masyarakat dapat mempelajari di mana saja dan kapan saja (PDKLP. 2011:21). Adapun kajian terhadap produk tersebut produk secara umum, meliputi : a) desain fisik; b) desain teks; dan c) desain bahasa.

a. Desain Fisik

Desain fisik yang dimaksud dalam buku modul pelatihan pembuatan geabah ini meliputi cover dan ukuran produk. Kedua hal tersebut diuraikan sebagai berikut :

1. Cover

Modul pelatihan pembuatan gerabah berisi ilustrasi yang menggambarkan berbagai jenis sumber daya alam dan hubungannya dengan manusia. Cover tersebut dicetak pada kertas dengan latar putih agar mudah dipadukan dan kontras dengan tulisan dan gambar yang disajikan. Hal demikian memudahkan masyarakat dalam membaca dan memaknai pesan dalam cover tersebut.

2. Ukuran Produk

Ukuran buku modul yang dikembangkan sederhana tidak terlalu kecil dan juga tidak terlalu besar, hal ini di karenakan ukuran tersebut dapat memudahkan masyarakat dalam membawa ke mana saja dan masyarakat dapat mempelajari buku modul tersebut dimana saja. Serta juga dapat mengajarkan tentang kerajinan gerabah kepada anak-anaknya sejak dini, karena buku 
modul pelatihan pembuatan gerabah ini ringan dan mudah untuk dipelajari dimana saja dan kapanpun sesuai keinginan.

b. Desain Teks

Teks merupakan aspek yang sangat penting di dalam sebuah buku modul/bahan ajar. Hal itu karena teks memuat pesan esensial yang harus sampai kepada pembaca (masyarakat). Penyajian teks dalam buku modul dilakukan sedemikian rupa agar mudah dan nyaman untuk dibaca. Beberapa hal yang terkait dengan hal tersebut, antara lain : 1) ukuran dan jenis huruf; 2) spasi.

Jenis huruf yang digunakan dalam buku modul adalah Times New Roman. Adapun ukuran huruf (font) yang berbeda-beda yakni 12 untuk huruf pada suatu teks dalam paragraf dan soal dan 8 untuk keterangan gambar.

Penggunaan spasi dalam buku modul ini juga menjadi perhatian penting karena berfungsi sebagai pemberi jarak fan pemisah kata, huruf, angka atau tanda baca. Selain menjadi pemisah antar kata dalam suatu kalimat (horizontal) penggunaan spasi juga berlaku sebagai pemberi jarak dan pemisah antar paragraph (vertikal). Penggunaan spasi yang baik akan memberikan kenyamanan bagi pembaca.

c. Desain Bahasa

Bahasa yang digunakan dalam buku modul ini sesuai dengan kaidah penggunaan Bahasa Indonesia yang baik dan benar yakni ejaan 
yang disempurnakan (EYD). Degen (2008:1) mengemukakan bahwa bahasa yang digunakan dalam penulisan bahan ajar bukan bahasa buku teks yang bersifat sangat resmi atau sangat formal melainkan bahasa yang setengah formal setengah lisan. Ketika menulis buku modul pelatihan pembuatan gerabah ini penulis harus membayangkan bahwa seolah-olah dia sedang mengajak pembaca berbicara. Agar pembaca bisa cepat dalam memahami buku modul pelatihan pembuatan gerabah ini.

d. Desain Visual

Desain visual yang dimaksud disini adalah terkait dengan penggunaan warna, gambar serta ilustrasi pada buku modul pelatihan pembuatan gerabah. Adapun pemaparan penggunaan warna, gambar dan juga ilustrasi yang akan disajikan sebagai berikut :

Penggunaan warna dalam buku modul pelatihan pembuatan gerabah ini terdapat pada hampir semua bagian buku modul, seperti background, tulisan dan garis tepi pada beberapa aspek. Warna dalam buku modul pelatihan pembuatan gerabah pastinya memiliki daya tarik tersendiri bagi masyarakat. Smaldino dkk (2011) mengemukakan bahwa warna berfungsi meningkatkan retensi dan meningkatkan motivasi agar perhatian pembelajar lebih fokus. Pett dan Wilson (dalam Smaldino dkk, 2011:83) juga memberikan alasan-alasan terkait dengan penggunaan warna dalam menyajikan materi dalam suatu pembelajaran, yakni 1) untuk menambah realitas, 2) untuk 
membedakan antara unsur-unsur sebuah visual, 3) untuk memfokuskan perhatian pada isyarat-isyarat yang relevan, 4) untuk mengkodekan dan mengkaitkan secara respon emosional. Selain itu agar penggunaan warna dalam bukumodul pelatihan pembuatan gerabah menjadi optimal dan tidak mengganggu pesan yang terkandung di dalamnya, Smaldino dkk (2011:89) mengemukakan bahwa warna teks seharusnya kontras dengan warna latar belakangnya agar mudah untuk dibaca. Berdasarkan uraian diatas, buku modul pelatihan pembuatan gerabah menggunakan warna biru gelap sebagai warna Background pada sebagian besar halaman, sedangkan teksnya menggunakan warna campuran (kuning, hitam, dan putih). Hal tersebut bertujuan untuk mendapatkan kejelasan dan kemudahan dalam membaca buku modul pelatihan pembuatan gerabah, sehingga pesan dalam teks dapat tersampaikan dengan baik kepada pembaca dan juga dapat memberi kesan yang menarik dari buku modul pelatihan pembuatan gerabah tersebut. Adapun pada bagian dalam buku modul pelatihan pembuatan gerabah hanya menggunakan warna hitam.

Buku modul pelatihan pembuatan gerabah didesain dengan penggunaan gambar dalam berbagai hal. Hal tersebut bertujuan untuk menarik perhatian masyarakat dan menghadirkan berbagai contoh dalam suatu bentuk gambar nyata. Adapun gambar yang digunakan di dalam buku modul pelatihan pembuatan gerabah ini terdiri dari gambar 
suatu objek yang langsung di dokumentasikan oleh peneliti dan beberapa foto yang diunduh dari internet.

\section{e. Komponen Isi}

Buku modul yang dikembangkan terdiri dari buku modul pelatihan dan panduan pelatihan. Sebaian besar isi buku modul yang terdapat pada modul pelatihan pembuatan gerabah sama dengan yang di panduan pelatihan. Adapun beberapa hal seperti silabus dan tata cara penggunaan buku modul hanya terdapat pada panduan pelatihan. Berikut pemaparan isi buku modul pelatihan pembuatan gerabah.

1) Kata Pengantar

Kata pengantar disajikan dalam satu halaman dengan bacgroundjudul biru muda serta diketik dengan huruf warna (hitam, putih dan kuning) jenis huruf time new roman dengan ukuran 12. Kata pengantar berisi ucapan syukur penulis atas terseikannya buku modul pelatihan pembuatan gerabah. Selain itu karakteristik buku modul pelatihan serta isi buku modul pelatihan di sampakan dihalaman tersebut. Harapan penulis terhadap kebermanfaatan buku modul pelatihan bagi masyarakat, pendidikan dan lingkungan alam menjadi point penutup. Dipojok kanan bawah terdapat identitas penulis.

2) Daftar Isi

Daftar isi memuat judul bab, judul sub bab, dan judul kegiatan yang disertai dengan nomor halaman didalam teks. Hal 
tersebut menggambarkan garis besar organisasi keseluruhan isi buku modul pelatihan.

3) Daftar Gambar

Daftar gambar berisi nomor gambar, keterangan gambar serta letak halamannya didalam buku modul pelatihan. Daftar gambar ini membantu masyarakat untuk menemukan gambar dengan mudah tanpa harus membolak balikkan lembaran buku modul pelatihan satu persatu.

4) Petunjuk PenggunaanModul Pelatihan

Pentunjuk penggunaan modul pelatihan berisi tujuan atau ilustrasi yang menggambarkan kegiatan yang akan dilaksanakan dalam kegiatan pembelajaran menggunakan panduan pelatihan. Ilustrasi tersebut didukung dengan kalimat penjelas terkait apa yang harus masyarakat lakukan. Kalimat tersebut ditulis secara ringkas dan padat sehingga mudah dipahami masyarakat.

5) Judul Tema, Sub Tema, dan Materi

Halaman ini berisi tentang judul tema, sub tema, dan materi yang akan dipelajari didalam kegiatan pelatihan dengan menggunakan buku modul dan panduan pelatihan. Bagian ini juga menjadi penanda untuk memulai kegiatan pembelajaran.

6) Evaluasi Diri

Evaluasi merupakan sebuah soal yang terkait dengan bahasan atau materi pelatihan yang dibahas. Adanya evaluasi ini 
berfungsi untuk membantu instruktur sebagai fasilitator dalam mengembangkan wawasan masyarakat terkait materi yang dipelajari masyarakat.

7) Daftar Rujukan

Daftar rujukan berisi sumber informasi yang digunakan dalam menulis dan mengembangkan buku modul pelatihan. Pengguna, baik instruktur maupun masyarakat dapat mengakses langsung halaman yang di cantumkan. Selain itu daftar rujukan berisi sumber kutipan atau rujukan yang digunakan penulis dalam bahan ajarnya. Hal demikian harus diperhatikan guna menghindari plagiasi.

\section{Kajian Produk Akhir}

Produk pengembangan buku modul pelatihan pembuatan gerabah sebagai panduan untuk masyarakat dalam pembuatan gerabah secara praktis dalam kaitannya dengan aktivitas ekonomi masyarakat, sesuai dengan revisi tahap I oleh ahli materi/isi, bahasa dan desain, tahap II oleh pemilik usaha kerajinan gerabah, dan revisi tahap III dilakukan berdasarkan hasil analisis data uji coba lapangan masyarakat Desa Masbagik Timur. Berdasarkan uji coba lapangan, deskripsi kualitas produk buku modul pelatihan pembuatan gerabah, yakni sebagai berikut:

a. Aspek keterlaksanaan dalam belajar masyarakat akan semakin mudah, karena meliputi keterampilan atau potensi yang ada pada lingkungan sekitar masyarakat.

b. Buku modul menarik perhatian masyarakat dalam belajar.

c. Isi dalam buku modul memberikan semangat untuk masyarakat yang mau memulai usaha dari awal.

d. Materi yang disajikan mudah dipahami oleh masyarakat khususnya. 
e. Kemenarikan gambar sangat baik.

f. Kejelasan gambar sangat baik.

g. Kejelasan ukuran huruf baik.

h. Kejelasan petunjuk bagi warga belajar juga sangat baik.

\section{KESIMPULAN}

Dalam bab ini dipaparkan kesimpulan proses pengembangan modul pelatihan pembuatan gerabah yang menghasilkan produk berupa buku modul dan hasil keefektifan dalam penyusunan modul pelatihan pembuatan gerabah.

1. Melalui tahap validasi dan uji coba produk ini sehingga dapat menghasilkan modul pelatihan pembuatan yang sangat praktis dan mudah dipahami oleh masyarakat. Berdasarkan data yang terkumpul dalam analisis pengembangan modul pelatihan pembuatan gerabah setelah di validator oleh beberapa ahli (ahli materi/isi, bahasa dan desain). Dari validasi ahli materi/isi memperoleh nilai rata-rata sebesar 3,6 \% dan termasuk kategori cukup valid, ahli bahasa memperoleh nilai rata-rata sebesar 3,1 dan termasuk kategori cukup valid, ahli desain memperoleh nilai rata-rata sebesar 1,1 dan termasuk kategori cukup valid. Setelah dilakukan validasi dan merevisi produk yang dihasilkan dari para ahli barulah diuji coba dilapangan (pemilik usaha dan masyarakat) sehingga dapat ditarik kesimpulan bahwa pengembangan buku modul pelatihan pembuatan gerabah ini dapat diketahui bahwa cocok digunakan di Desa Masbagik Timur sebagai bahan ajar untuk masyarakat yang ingin memulai usaha kerajinan gerabah.

2. Keefektifan Modul Pelatihan Pembuatan Gerabah dapat dilihat dari respon masyarakat yang mendapatkan nilai persentase rata-rata sebesar 3,7 \% dan respon pemilik usaha kerajinan gerabah mendapatkan nilai persentase rata-rata sebesar 2,9\%. Dari hasil nilai yang diperoleh melalui respon masyarakat dan pemilik usaha kerajinan gerabah dapat di katakana efektif untuk digunakan oleh masyarakat Desa Masbagik Timur. 


\section{DAFTAR RUJUKAN}

Anwar, Ilham. 2010. Pengembangan Bahan Ajar. Bahan Kuliah Online. Direktri UPI. Bangdung.

Kemendikbud. (2014). Buku Guru; Prakarya dan Kewirausahaan. Jakarta : Kementrian Pendidikan dan Kebudayaan.

Sugiyono. 2015. Metodologi Penelitian \& Pengembangan Reseach and Development. Bandung : Alfabeta

Suparman, Atwi. 1997. Desain Instruktional. Jakarta : Rineka Cipta

Suryaningsih, Nunik Setiyo. 2010. Pengembangan media cetak modul sebagai media pembelajaran mandiri pada mata pelajaran teknologi informatika dan komunikasi kelas VII semester 1 di SMPN Jombang Surabaya : Skripsi yang tidak dipublikasikan.

Utomo, Tjipto. 1991. Peningkatan dan Pengembangan Pendidikan. Jakarta : Granmedia Pustaka Utama.

Vembriarto, St. 1975. Pengantar Pengajaran Modul. Yogyakarta.

Wijaya, Cece,.dkk. 1988. Upaya Pembaharuan Dalam Pendidikan dan Pengajaran. Bandung : Remadja Karya

Winkel. 2009. Psikologi Pengajaran. Yogyakarta : Media Abadi. 